\title{
LEVEL II SCOUR ANALYSIS FOR BRIDGE 12 (BRAITH00230012) on TOWN HIGHWAY 23, crossing AYERS BROOK, BRAINTREE, VERMONT
}

U.S. Geological Survey Open-File Report 96-390

Prepared in cooperation with

VERMONT AGENCY OF TRANSPORTATION and

FEDERAL HIGHWAY ADMINISTRATION 


\section{LEVEL II SCOUR ANALYSIS FOR BRIDGE 12 (BRAITH00230012) on TOWN HIGHWAY 23, crossing AYERS BROOK, BRAINTREE, VERMONT \\ By SCOTT A. OLSON}

U.S. Geological Survey Open-File Report 96-390

Prepared in cooperation with

VERMONT AGENCY OF TRANSPORTATION and

FEDERAL HIGHWAY ADMINISTRATION 


\title{
U.S. DEPARTMENT OF THE INTERIOR BRUCE BABBITT, Secretary
}

\author{
U.S. GEOLOGICAL SURVEY \\ Gordon P. Eaton, Director
}

For additional information write to:

District Chief

U.S. Geological Survey 361 Commerce Way

Pembroke, NH 03275-3718
Copies of this report may be purchased from:

U.S. Geological Survey Earth Science Information Center Open-File Reports Section Box 25286, MS 517 Federal Center

Denver, CO 80225 


\section{CONTENTS}

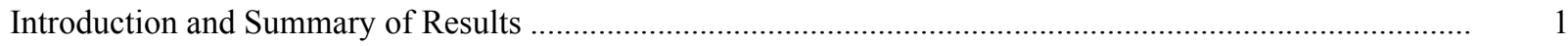

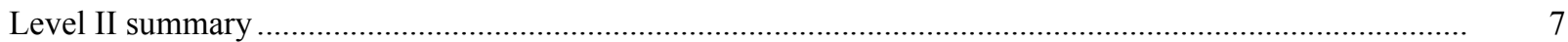

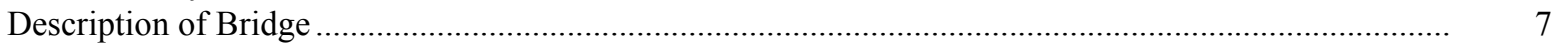

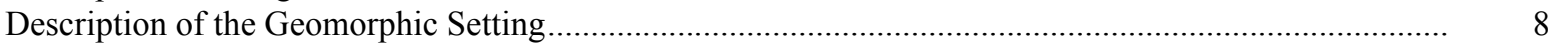

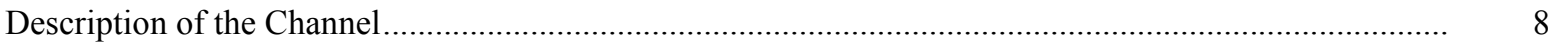

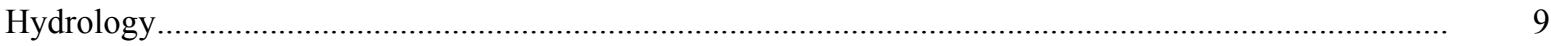

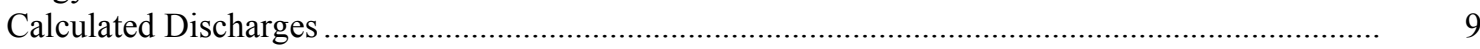

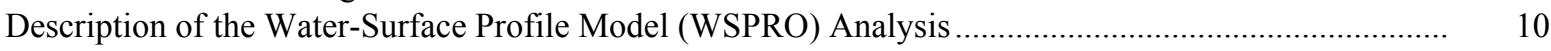

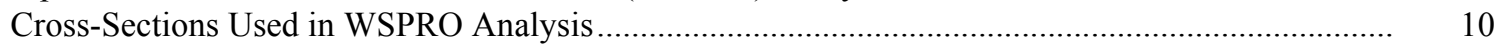

Data and Assumptions Used in WSPRO Model ...................................................................... 11

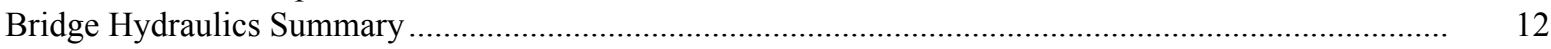

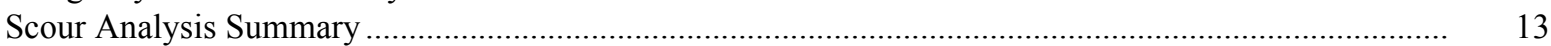

Special Conditions or Assumptions Made in Scour Analysis ...................................................... 13

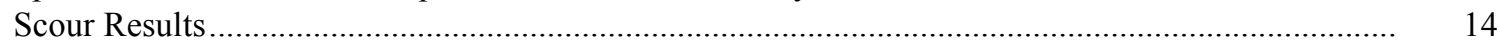

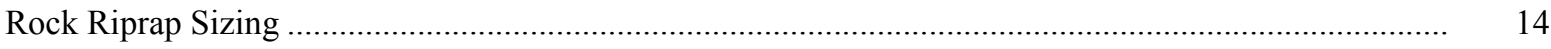

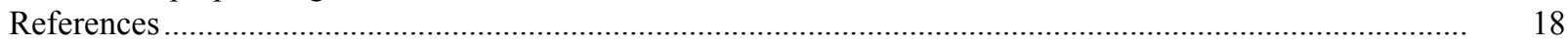

Appendixes:

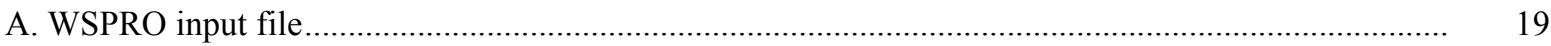

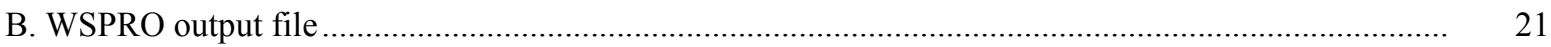

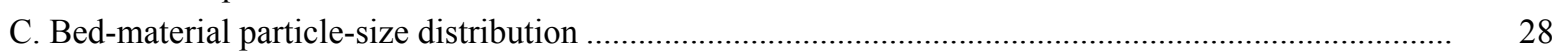

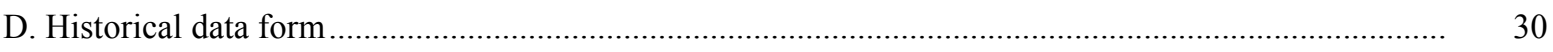

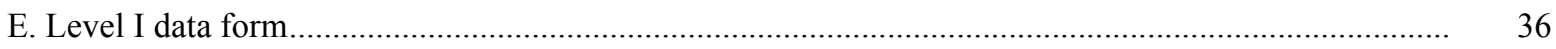

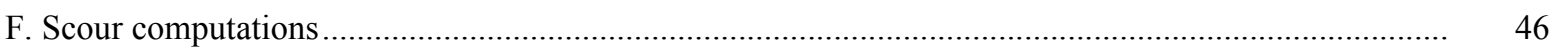

\section{FIGURES}

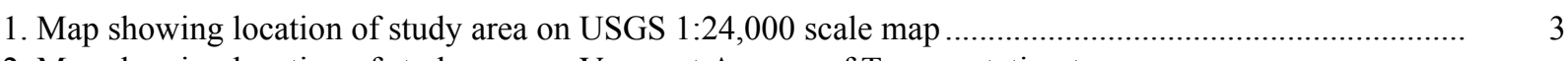

2. Map showing location of study area on Vermont Agency of Transportation town
highway map

3. Structure BRAITH00230012 viewed from upstream (November 16, 1994) ........................................... 5

4. Downstream channel viewed from structure BRAITH00230012 (November 16, 1994)........................ 5

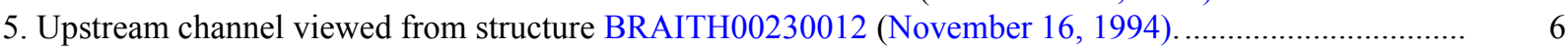

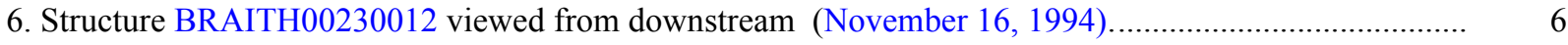

7. Water-surface profiles for the 100- and 500-year discharges at structure

BRAITH00230012 on Town Highway 23, crossing Ayers Brook,

Braintree, Vermont.

8. Scour elevations for the 100- and 500-year discharges at structure

BRAITH00230012 on Town Highway 23, crossing Ayers Brook,

Braintree, Vermont.

\section{TABLES}

1. Remaining footing/pile depth at abutments for the 100-year discharge at structure

BRAITH00230012 on Town Highway 23, crossing Ayers Brook,

Braintree, Vermont.

2. Remaining footing/pile depth at abutments for the 500-year discharge at structure

BRAITH00230012 on Town Highway 23, crossing Ayers Brook,

Braintree, Vermont.

5
(5 


\begin{tabular}{|c|c|c|}
\hline Multiply & By & To obtain \\
\hline \multicolumn{3}{|c|}{ Length } \\
\hline inch (in.) & 25.4 & millimeter (mm) \\
\hline foot $(\mathrm{ft})$ & 0.3048 & $\operatorname{meter}(\mathrm{m})$ \\
\hline mile (mi) & 1.609 & kilometer (km) \\
\hline \multicolumn{3}{|c|}{ Slope } \\
\hline foot per mile ( $\mathrm{ft} / \mathrm{mi})$ & 0.1894 & meter per kilometer $(\mathrm{m} / \mathrm{km})$ \\
\hline \multicolumn{3}{|c|}{ Area } \\
\hline square mile $\left(\mathrm{mi}^{2}\right)$ & 2.590 & square kilometer $\left(\mathrm{km}^{2}\right)$ \\
\hline \multicolumn{3}{|c|}{ Volume } \\
\hline cubic foot $\left(\mathrm{ft}^{3}\right)$ & $\begin{array}{l}0.02832 \\
\text { Velocity and Flow }\end{array}$ & cubic meter $\left(\mathrm{m}^{3}\right)$ \\
\hline foot per second $(\mathrm{ft} / \mathrm{s})$ & 0.3048 & meter per second $(\mathrm{m} / \mathrm{s})$ \\
\hline cubic foot per second $\left(\mathrm{ft}^{3} / \mathrm{s}\right)$ & 0.02832 & cubic meter per second $\left(\mathrm{m}^{3} / \mathrm{s}\right)$ \\
\hline $\begin{array}{l}\text { cubic foot per second per } \\
\text { square mile } \\
{\left[\left(\mathrm{ft}^{3} / \mathrm{s}\right) / \mathrm{mi}^{2}\right]}\end{array}$ & 0.01093 & $\begin{array}{l}\text { cubic meter per } \\
\text { second per square } \\
\text { kilometer }\left[\left(\mathrm{m}^{3} / \mathrm{s}\right) / \mathrm{km}^{2}\right]\end{array}$ \\
\hline
\end{tabular}

OTHER ABBREVIATIONS

$\begin{array}{lrlr}\mathrm{BF} & \text { bank full } & \text { LWW } & \text { left wingwall } \\ \mathrm{cfs} & \text { cubic feet per second } & \text { MC } & \text { main channel } \\ \mathrm{D}_{50} & \text { median diameter of bed material } & \text { RAB } & \text { right abutment } \\ \mathrm{DS} & \text { downstream } & \text { RABUT } & \text { face of right abutment } \\ \mathrm{elev} & \text { elevation } & \text { RB } & \text { right bank } \\ \mathrm{f} / \mathrm{p} & \text { flood plain } & \text { ROB } & \text { right overbank } \\ \mathrm{ft} & \text { square feet } & \text { RWW } & \text { right wingwall } \\ \mathrm{ft} / \mathrm{ft} & \text { feet per foot } & \text { TH } & \text { town highway } \\ \mathrm{JCT} & \text { junction } & \text { UB } & \text { under bridge } \\ \mathrm{LAB} & \text { left abutment } & \text { US } & \text { upstream } \\ \mathrm{LABUT} & \text { face of left abutment } & \text { USGS } & \text { United States Geological Survey } \\ \text { LB } & \text { left bank } & \text { VTAOT Vermont Agency of Transportation } \\ \text { LOB } & \text { left overbank } & \text { WSPRO } & \text { water-surface profile model }\end{array}$

In this report, the words "right" and "left" refer to directions that would be reported by an observer facing downstream. Sea level: In this report, "sea level" refers to the National Geodetic Vertical Datum of 1929-- a geodetic datum derived from a general adjustment of the first-order level nets of the United States and Canada, formerly called Sea Level Datum of 1929.

In the appendices, the above abbreviations may be combined. For example, USLB would represent upstream left bank. 


\title{
LEVEL II SCOUR ANALYSIS FOR BRIDGE 12 (BRAITH00230012) ON TOWN HIGHWAY 23, CROSSING AYERS BROOK, BRAINTREE, VERMONT
}

\author{
By Scott A. Olson
}

\section{INTRODUCTION AND SUMMARY OF RESULTS}

This report provides the results of a detailed Level II analysis of scour potential at structure BRAITH00230012 on town highway 23 crossing Ayers Brook, Braintree, Vermont (figures $1-8)$. A Level II study is a basic engineering analysis of the site, including a quantitative analysis of stream stability and scour (U.S. Department of Transportation, 1993). A Level I study is included in Appendix E of this report. A Level I study provides a qualitative geomorphic characterization of the study site. Information on the bridge available from VTAOT files was compiled prior to conducting Level I and Level II analyses and can be found in Appendix D.

The site is in the Green Mountain physiographic province of central Vermont in the town of Braintree. The $18.8-\mathrm{mi}^{2}$ drainage area is in a predominantly rural watershed. In the vicinity of the study site, the surface cover of the left and right banks is pasture .

In the study area, Ayers Brook has a meandering channel with a slope of approximately $0.003 \mathrm{ft} / \mathrm{ft}$, an average channel top width of $46 \mathrm{ft}$ and an average channel depth of $5 \mathrm{ft}$. The predominant channel bed material is sand and gravel $\left(\mathrm{D}_{50}\right.$ is $6.15 \mathrm{~mm}$ or $\left.0.0202 \mathrm{ft}\right)$. The geomorphic assessment at the time of the Level I and Level II site visit on November 16, 1994, indicated that the reach was laterally unstable. Also at the time of the site visit, there was considerable backwater at the bridge site due to a beaver dam downstream. The beaver dam was ignored in the analyses.

The town highway 23 crossing of Ayers Brook is a 28 -ft-long, one-lane bridge consisting of one 23-foot span (Vermont Agency of Transportation, written communication, August 24, 1994). The bridge is supported by vertical timber cribwork abutments with wingwalls on the upstream and downstream sides of the right abutment. The lower half of the right abutment and wingwalls are constructed of laid-up stone. The right abutment and wingwalls are also protected by stone fill. The channel is skewed approximately 45 degrees to the opening while the opening-skew-to-roadway is only 5 degrees. Additional details describing conditions at the site are included in the Level II Summary and Appendices $\mathrm{D}$ and $\mathrm{E}$. 
Scour depths and rock rip-rap sizes were computed using the general guidelines described in Hydraulic Engineering Circular 18 (Richardson and others, 1993). Total scour at a highway crossing is comprised of three components: 1) long-term streambed degradation; 2) contraction scour (due to accelerated flow caused by a reduction in flow area at a bridge) and; 3) local scour (caused by accelerated flow around piers and abutments). Total scour is the sum of the three components. Equations are available to compute depths for contraction and local scour and a summary of the results of these computations follows.

Contraction scour for all modelled flows ranged from 4.2 to $9.4 \mathrm{ft}$. The worst-case contraction scour occurred at the incipient-overtopping discharge which was less than the 100 -year discharge. Abutment scour ranged from 4.3 to $17.5 \mathrm{ft}$. The worst-case abutment scour occurred at the 500-year discharge. Additional information on scour depths and depths to armoring are included in the section titled "Scour Results". Scoured-streambed elevations, based on the calculated scour depths, are presented in tables 1 and 2. A crosssection of the scour computed at the bridge is presented in figure 8. Scour depths were calculated assuming an infinite depth of erosive material and a homogeneous particle-size distribution.

It is generally accepted that the Froehlich equation (abutment scour) gives "excessively conservative estimates of scour depths" (Richardson and others, 1993, p. 48). Usually, computed scour depths are evaluated in combination with other information including (but not limited to) historical performance during flood events, the geomorphic stability assessment, existing scour protection measures, and the results of the hydraulic analyses. Therefore, scour depths adopted by VTAOT may differ from the computed values documented herein. 


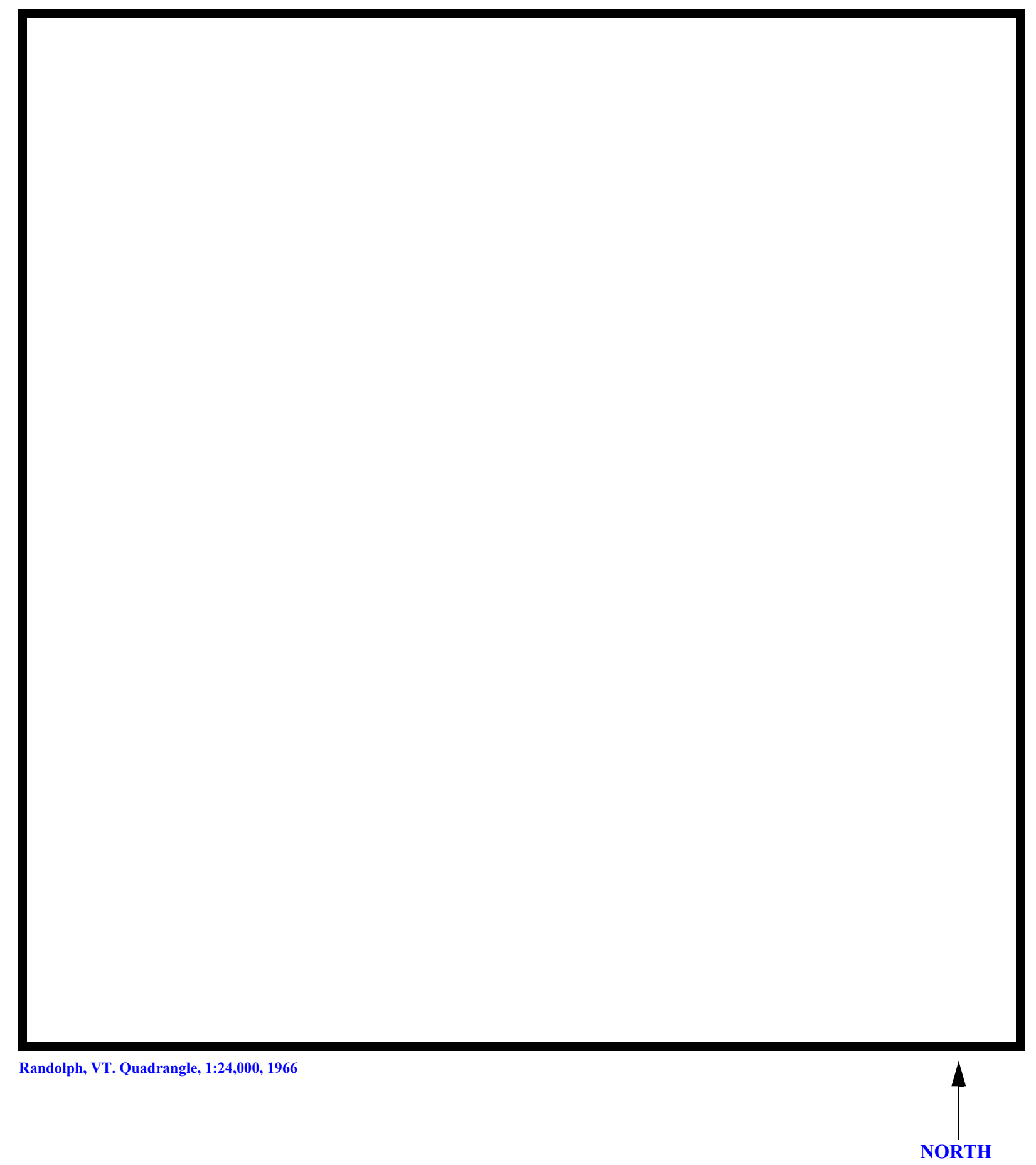

Figure 1. Location of study area on USGS 1:24,000 scale map. 
Figure 2. Location of study area on Vermont Agency of Transportation town highway map. 

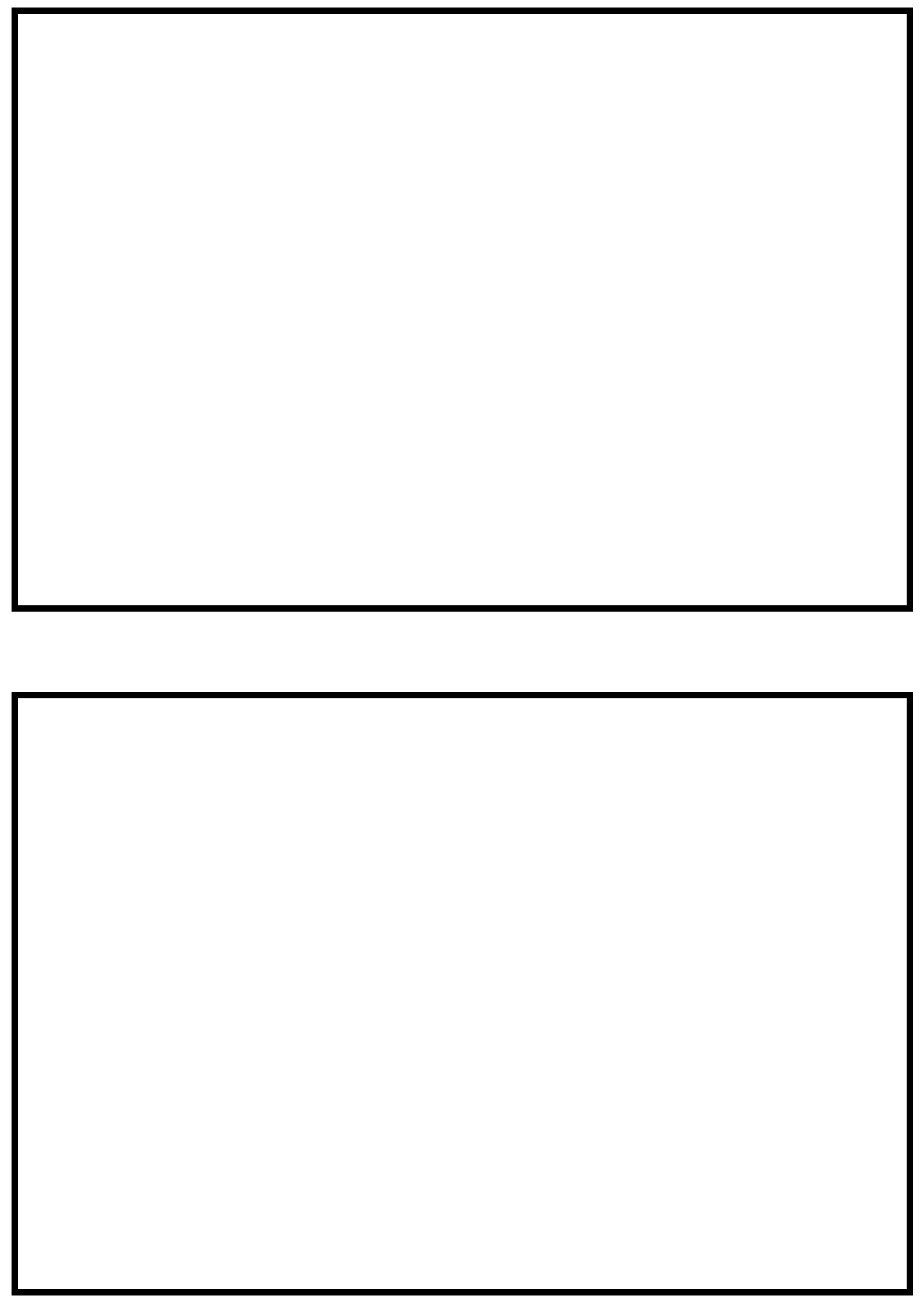

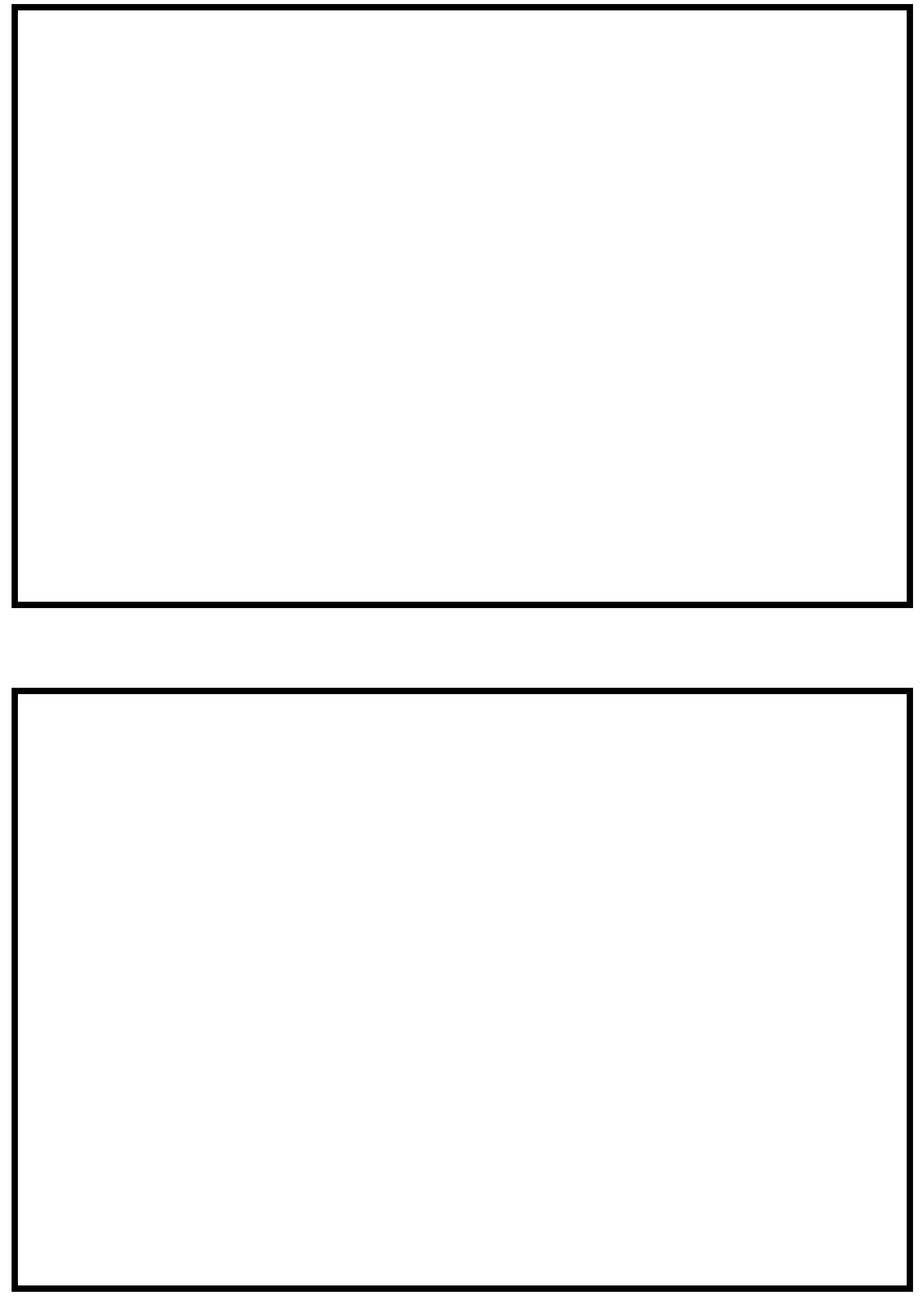


\section{LEVEL II SUMMARY}

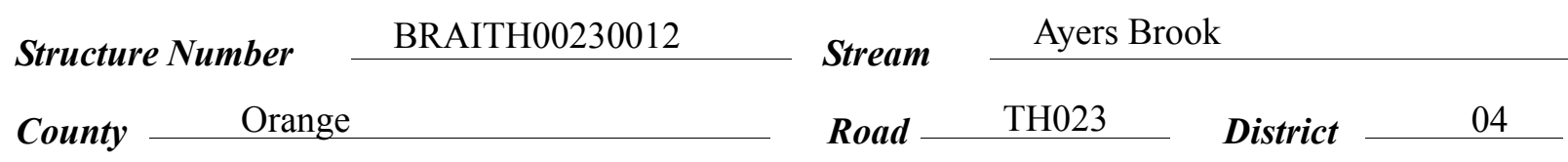

\section{Description of Bridge}

Bridge length $\frac{28}{2} \quad \boldsymbol{f t}$ Bridge width $f t \quad$ Max span length 23 ft Alignment of bridge to road (on curve or straight) Wood crib, laid-up stone

Abutment type

Stone fill on abutment? on right

Embankment type moderate curve on right approach

wingwall and type I protection on the upstream right wingwall. Stone fill appears to have slumped

into the main channel from the banks and toes of the banks.

There is a stone laid-up wall extending from the upstream end of the left abutment to about 75 feet upstream. This is protecting the roadway from being cut into by the channel. Part of right abutment is laid-up stone.

Is bridge skewed to flood flow according to. Y ' survey? $\quad \frac{\mathrm{Y}}{4}$ Angle

Ayers Brook is a meandering channel and there is a severe bend in the channel at the entrance to the bridge opening.

Debris accumulation on bridge at time of Level I or Level II site visit:

$$
\begin{gathered}
\text { Date of incnortion } \\
11 / 16 / 94 \\
\hline
\end{gathered}
$$

Level I

same

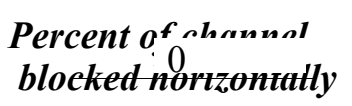

Percent of s.mel blocked verticatty

Level II

High due to severe bank cutting along channel meanders with some trees along the top of bank leaning over the brook.

Potential for debris

The lateral instability of the channel may cause the additional misalignment with the bridge. Doscriho anv fonturos noar ar at tho hridoo that mav, affort flow (includo ahsorvation dato) High debris potential could also affect flow. 


\section{Description of the Geomorphic Setting}

General topography Moderate relief valley with wide floodplains; stream meanders and anabranches throughout the wide valley.

Geomorphic conditions at bridge site: downstream (DS), upstream (US)

Date of inspection $\quad 11 / 16 / 94$

DS left: $\quad$ wide floodplain

DS right: $\quad$ narrow flood plain to valley wall

US left: $\quad$ wide floodplain

US right: $\quad$ narrow flood plain to valley wall

\section{Description of the Channel}

\begin{tabular}{|c|c|c|c|c|}
\hline & 46 & & 5 & \\
\hline Average top width & gravel $^{\boldsymbol{f t}}$ & Average depth & & $f t$ \\
\hline
\end{tabular}

wide flood plains. İ is alluviäl and laterally unstable.

$11 / 16 / 94$

Vegetative co 1 Pasture

DS left: $\quad$ Pasture

DS right: $\quad$ Pasture

US left: $\quad$ Pasture

US right:

$\mathrm{N}$

Do banks appear stable? 11/16/94--Cut-banks are common along this reach of the brook

Lateral instability is a concern especially due to the severe bend at the channel entrance to the
date of observatton. bridge opening.

beaver dam about 140 feet downstream of the bridge.

Describe any obstructions in channel and date of observation. 


\title{
Hydrology
}

Drainage area $\frac{18.8}{\boldsymbol{m i}^{2}}$

Percentage of drainage area in physiographic provinces: (approximate)

Physiographic province

Green Mountain
Percent of drainage area

100

\begin{abstract}
Is drainage area considered rural or urban?
Rural

urbanization: None

Describe any significant
\end{abstract}

\begin{tabular}{ccc} 
Is there a USGS gage on the stream of interest? & \multicolumn{1}{c}{$\begin{array}{c}\text { Yes } \\
\text { Ayers Brook at Randolph, VT }\end{array}$} \\
& USGS gage description & 01142500 \\
\end{tabular}

USGS gage number

30.5

Gage drainage area $\mathrm{mi}^{2}$

No

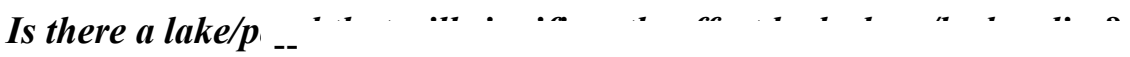

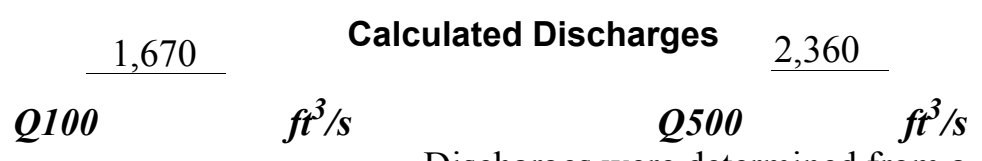

Discharges were determined from a drainage area

relationship with flood frequency determinations at the Ayers Brook gaging station. The discharges at the gaging station were determined from a statistical analysis of the long term continuous flow record (Interagency Advisory Committee on Water Data, 1982). 


\section{Description of the Water-Surface Profile Model (WSPRO) Analysis}

Datum for WSPRO analysis (USGS survey, sea level, VTAOT plans)

USGS survey

Datum tie between USGS survey and VTAOT plans

N/A

Description of reference marks used to determine USGS datum. $\quad$ RM1 is near the

downstream left corner of the bridge. It is the head of a spike in the top streamward end of the

topmost $\log$ in the abutment cribwork. The arbitrary survey elevation is 999.86 feet

\section{Cross-Sections Used in WSPRO Analysis}

\begin{tabular}{cccl}
\hline${ }^{1}$ Cross-section & $\begin{array}{c}\text { Section } \\
\text { Reference } \\
\text { Distance } \\
\text { (SRD) in feet }\end{array}$ & $\begin{array}{c}{ }^{2} \text { Cross-section } \\
\text { development }\end{array}$ & \multicolumn{1}{c}{ Comments } \\
\hline EXIT1 & -52 & 1 & Exit section \\
FULLV & 0 & 2 & $\begin{array}{l}\text { Downstream Full-valley } \\
\text { section (Templated from } \\
\text { EXIT1) } \\
\text { BRIDG }\end{array}$ \\
RDWAY & 0 & 1 & Bridge section \\
APPR & 10 & 1 & Road Grade section \\
& 46 & 1 & Approach section \\
\hline
\end{tabular}

${ }^{1}$ For location of cross-sections see plan-view sketch included with Level I field form, Appendix E. For more detail on how cross-sections were developed see WSPRO input file. 


\section{Data and Assumptions Used in WSPRO Model}

Hydraulic analyses of the reach were done by use of the Federal Highway Administration's WSPRO step-backwater computer program (Shearman and others, 1986, and Shearman, 1990). The analysis reported herein reflects conditions existing at the site at the time of the study. Furthermore, in the development of the model it was necessary to assume no accumulation of debris or ice at the site. Results of the hydraulic model are presented in the Bridge Hydraulic Summary, Appendix B, and figure 7.

Channel roughness factors (Manning's " $n$ ") used in the hydraulic model were estimated using field inspections at each cross section following the general guidelines described by Arcement, Jr. and Schneider (1989). Final adjustments to the values were made during the modelling of the reach. Channel " $\mathrm{n}$ " values for the reach ranged from 0.034 to 0.050 , and overbank " $\mathrm{n}$ " values ranged from 0.030 to 0.040 .

Normal depth at the exit section (EXIT1) was assumed as the starting water surface. This depth was computed by use of the slope-conveyance method outlined in the user's manual for WSPRO (Shearman, 1990). The slope used was $0.003 \mathrm{ft} / \mathrm{ft}$ which was determined from surveyed thalweg points downstream of the bridge.

The surveyed approach section (APPR) was surveyed one bridge length upstream of the upstream face as recommended by Shearman and others (1986). This approach also provides a consistent method for determining scour variables.

For the incipient overtopping model, WSPRO assumes critical depth at the bridge section. Further analysis, in which the water surface is shown to pass through critical depth in the bridge, suggests the critical depth assumption at the bridge section is a satisfactory solution. 


\section{Bridge Hydraulics Summary}

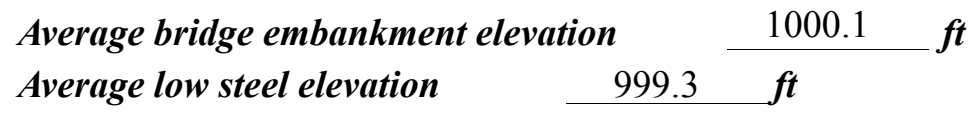

100-year discharge $\quad 1,670 \quad \mathrm{ft}^{3} / \mathrm{s}$

Water-surface elevation in bridge opening $\quad 999.5 \quad f t$

Road overtopping? ___ yes Discharge over road _ $700, \ldots$ s

Area of flow in bridge opening $\quad 148 \quad \mathrm{ft}^{2}$

Average velocity in bridge opening $\quad \begin{array}{lll}6.6 & \mathrm{ft} / \mathrm{s}\end{array}$

Maximum WSPRO tube velocity at bridge $\quad 8.4 \quad \mathrm{ft} / \mathrm{s}$

Water-surface elevation at Approach section with bridge $\quad 1000.2$

Water-surface elevation at Approach section without bridge $\quad 996.2$

Amount of backwater caused by bridge $\quad 4.0$ it

500-year discharge $\quad 2,360 \quad \mathrm{ft}^{3} / \mathrm{s}$

Water-surface elevation in bridge opening

$999.5 f t$

Road overtopping? ___ yes Discharge over road _ $1237 \mathrm{~J} / \mathrm{s}$

Area of flow in bridge opening $\quad 148 \quad \mathrm{ft}^{2}$

Average velocity in bridge opening $\quad 7.5 \mathrm{ft} / \mathrm{s}$

Maximum WSPRO tube velocity at bridge 9.6 _'s

Water-surface elevation at Approach section with bridge

Water-surface elevation at Approach section without bridge

1000.7

Amount of backwater caused by bridge 4.0 .

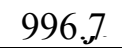

Incipient overtopping discharge $\quad 1,215 \mathrm{ft}^{3} / \mathrm{s}$

Water-surface elevation in bridge opening $\quad 995.5 \quad t$

Area of flow in bridge opening $\quad 89.0 \quad \mathrm{ft}^{2}$

Average velocity in bridge opening $\quad 13.6 \quad \mathrm{ft} / \mathrm{s}$

Maximum WSPRO tube velocity at bridge $\quad 17.8 \mathrm{ft} / \mathrm{s}$

Water-surface elevation at Approach section with bridge

Water-surface elevation at Approach section without bridge

Amount of backwater caused by bridge $\quad$\begin{tabular}{l}
3.2 it \\
\hline
\end{tabular}

998.9

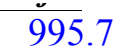




\section{Scour Analysis Summary}

\section{Special Conditions or Assumptions Made in Scour Analysis}

Scour depths were computed using the general guidelines described in Hydraulic Engineering Circular 18 (Richardson and others, 1993). Scour depths were calculated assuming an infinite depth of erosive material and a homogeneous particle-size distribution. The results of the scour analysis are presented in tables 1 and 2 and a graph of the scour depths is presented in figure 8 .

The 100-year and 500-year discharges resulted in unsubmerged orifice flow. Contraction scour at bridges with orifice flow is best estimated by use of the Chang pressureflow equation (oral communication, J. Sterling Jones, October 4, 1996). Therefore, contraction scour for the 100-year and 500-year discharges was computed by use of the Chang equation (Richardson and others, 1995, p. 145-146). The results of Laursen's clearwater contraction scour for the 100-year and 500-year events were also computed and can be found in appendix F. For the incipient road-overflow discharge, contraction scour was computed by use of the clear-water contraction scour equation (Richardson and others, 1993, p. 35, equation 18). Worst case contraction scour was at the incipient road overtopping discharge. The worst case total scour occurred at the 500-year discharge.

Because of the streambed's fine material composition, armoring was not applicable at this site, except for the 100-year discharge.

Abutment scour for the right abutment was computed by use of the Froehlich equation (Richardson and others, 1993, p. 49, equation 24). Variables for the Froehlich equation include the Froude number of the flow approaching the embankments, the length of the embankment blocking flow, and the depth of flow approaching the embankment less any roadway overtopping.

Scour at the left abutment was computed by use of the HIRE equation (Richardson and others, 1993, p. 50, equation 25) because the HIRE equation is recommended when the length to depth ratio of the embankment blocking flow exceeds 25 . The variables used by the HIRE abutment-scour equation are defined the same as those defined for the Froehlich abutment-scour equation. 


\section{Scour Results}

$$
\text { 100-yr discharge 500-yr discharge }
$$

Contraction scour:

Main channel

Live-bed scour

Clear-water scour

Depth to armoring

Left overbank

Right overbank

Local scour:

Abutment scour

Left abutment

Right abutment

Pier scour

Pier 1

Pier 2

Pier 3
(Scour depths in feet)
Incipient
rtopping
harge

(Scour depths infeet) 


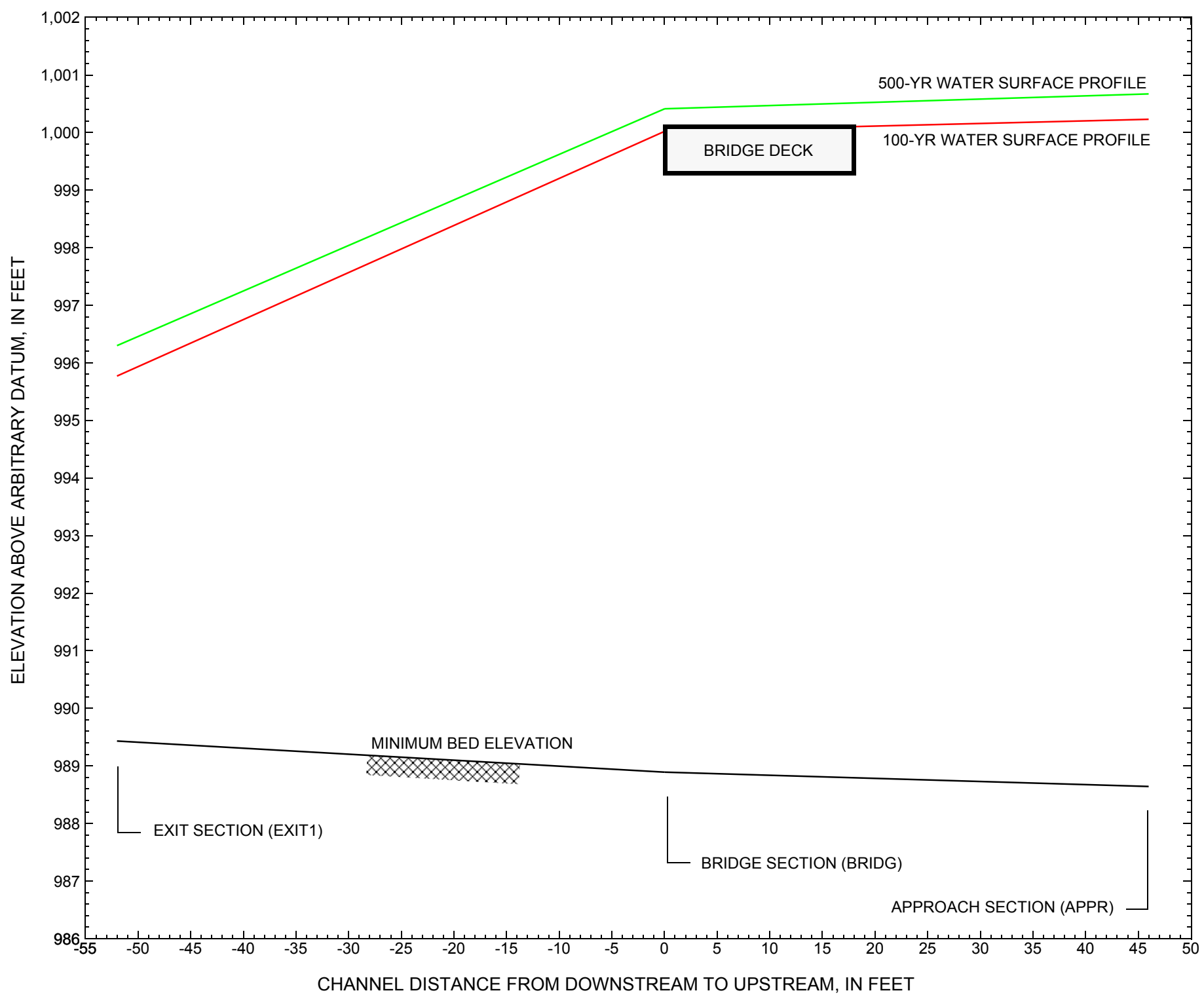

Figure 7. Water-surface profiles for the 100- and 500-yr discharges at structure BRAITH00230012 on town highway 23, crossing Ayers Brook, Braintree, Vermont. 


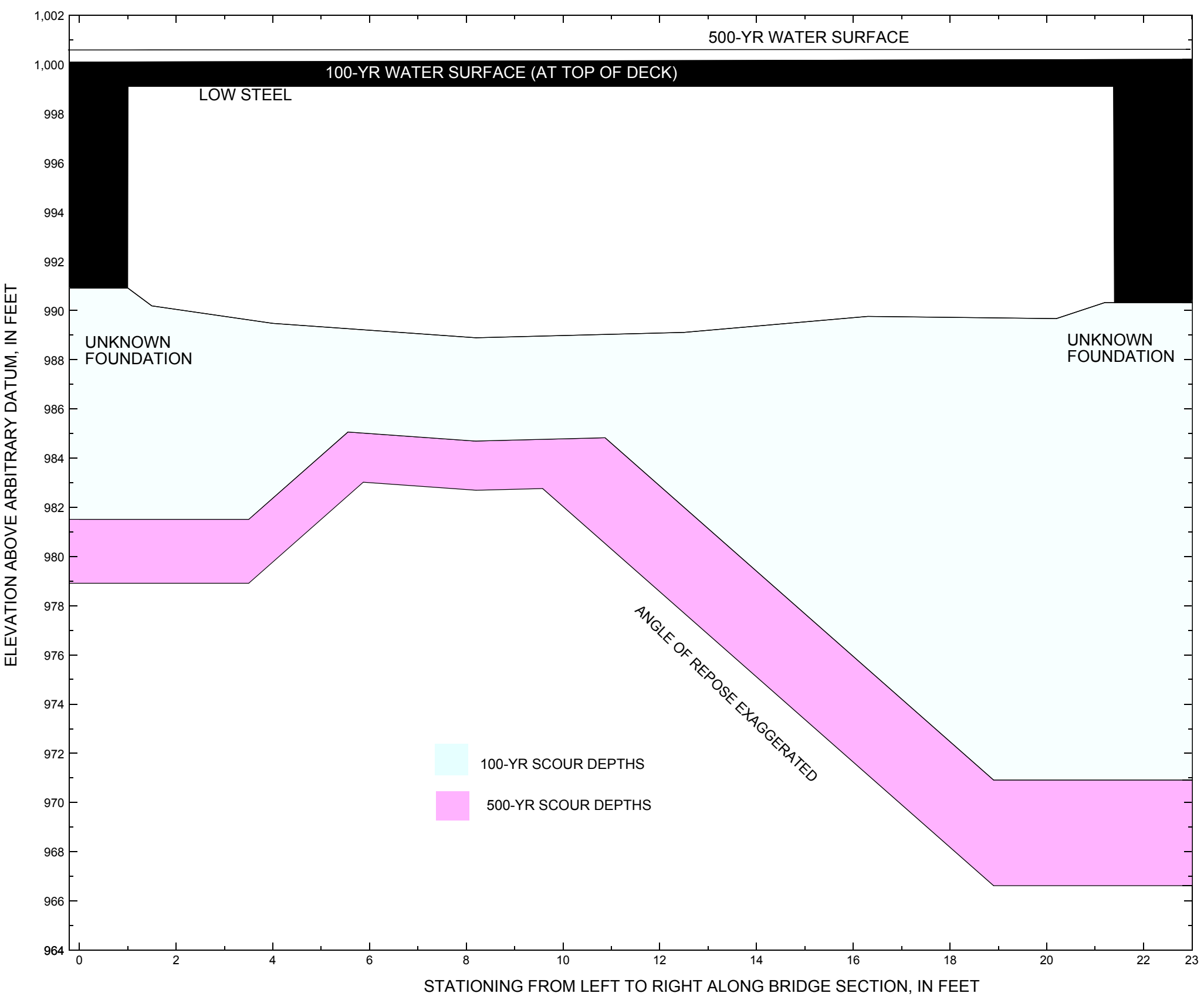

Figure 8. Scour elevations for the 100-yr and 500-yr discharges at structure BRAITH00230012 on town highway 23, crossing Ayers Brook, Braintree, Vermont. 
Table 1. Remaining footing/pile depth at abutments for the 100-year discharge at structure BRAITH00230012 on Town Highway 23, crossing Ayers Brook, Braintree, Vermont.

[VTAOT, Vermont Agency of Transportation; --,no data]

\begin{tabular}{|c|c|c|c|c|c|c|c|c|c|c|c|}
\hline Description & Station $^{1}$ & $\begin{array}{l}\text { VTAOT } \\
\text { minimum } \\
\text { low-chord } \\
\text { elevation } \\
\text { (feet) }\end{array}$ & $\begin{array}{l}\text { Surveyed } \\
\text { minimum } \\
\text { low-chord } \\
\text { elevation } \\
\text { (feet) }\end{array}$ & $\begin{array}{l}\text { Bottom of } \\
\text { footing } \\
\text { elevation } \\
\text { (feet) }\end{array}$ & $\begin{array}{c}\text { Channel } \\
\text { elevation at } \\
\text { abutment/ } \\
\text { pier }^{2} \\
\text { (feet) }\end{array}$ & $\begin{array}{l}\text { Contraction } \\
\text { scour depth } \\
\text { (feet) }\end{array}$ & $\begin{array}{l}\text { Abutment } \\
\text { scour } \\
\text { depth } \\
\text { (feet) }\end{array}$ & $\begin{array}{l}\text { Pier } \\
\text { scour } \\
\text { depth } \\
\text { (feet) }\end{array}$ & $\begin{array}{c}\text { Depth of } \\
\text { total scour } \\
\text { (feet) }\end{array}$ & $\begin{array}{c}\text { Elevation of } \\
\text { scour }^{2} \\
\text { (feet) }\end{array}$ & $\begin{array}{c}\text { Remaining } \\
\text { footing/pile } \\
\text { depth } \\
\text { (feet) }\end{array}$ \\
\hline \multicolumn{12}{|c|}{100 -yr. discharge is 1,670 cubic-feet per second } \\
\hline Left abutment & 1.0 & -- & 999.5 & -- & 990.9 & 4.2 & 5.2 & -- & 9.4 & 981.5 & -- \\
\hline Right abutment & 21.4 & -- & 999.1 & -- & 990.3 & 4.2 & 15.2 & -- & 19.4 & 970.9 & -- \\
\hline
\end{tabular}

1. Measured along the face of the most constricting side of the bridge.

2. Arbitrary datum for this study.

Table 2. Remaining footing/pile depth at abutments for the 500-year discharge at structure BRAITH00230012 on Town Highway 23, crossing Ayers Brook, Braintree, Vermont.

[VTAOT, Vermont Agency of Transportation; --, no data]

\begin{tabular}{|c|c|c|c|c|c|c|c|c|c|c|c|}
\hline Description & Station $^{1}$ & $\begin{array}{l}\text { VTAOT } \\
\text { minimum } \\
\text { low-chord } \\
\text { elevation } \\
\text { (feet) }\end{array}$ & $\begin{array}{c}\text { Surveyed } \\
\text { minimum } \\
\text { low-chord } \\
\text { elevation }{ }^{2} \\
\text { (feet) }\end{array}$ & $\begin{array}{c}\text { Bottom of } \\
\text { footing } \\
\text { elevation } \\
\text { (feet) }\end{array}$ & $\begin{array}{c}\text { Channel } \\
\text { elevation at } \\
\text { abutment/ } \\
\text { pier }^{2} \\
\text { (feet) }\end{array}$ & $\begin{array}{l}\text { Contraction } \\
\text { scour depth } \\
\text { (feet) }\end{array}$ & $\begin{array}{l}\text { Abutment } \\
\text { scour } \\
\text { depth } \\
\text { (feet) }\end{array}$ & $\begin{array}{l}\text { Pier } \\
\text { scour } \\
\text { depth } \\
\text { (feet) }\end{array}$ & $\begin{array}{l}\text { Depth of } \\
\text { total scour } \\
\text { (feet) }\end{array}$ & $\begin{array}{c}\text { Elevation of } \\
\text { scour }^{2} \\
\text { (feet) }\end{array}$ & $\begin{array}{c}\text { Remaining } \\
\text { footing/pile } \\
\text { depth } \\
\text { (feet) }\end{array}$ \\
\hline \multicolumn{12}{|c|}{500 -yr. discharge is 2,360 cubic-feet per second } \\
\hline Left abutment & 1.0 & -- & 999.5 & -- & 990.9 & 6.2 & 5.8 & -- & 12.0 & 978.9 & -- \\
\hline Right abutment & 21.4 & -- & 999.1 & -- & 990.3 & 6.2 & 17.5 & -- & 23.7 & 966.6 & -- \\
\hline
\end{tabular}

1. Measured along the face of the most constricting side of the bridge.

2. Arbitrary datum for this study. 
Arcement, G.J., Jr., and Schneider, V.R., 1989, Guide for selecting Manning's roughness coefficients for natural channels and flood plains: U.S. Geological Survey Water-Supply Paper 2339, 38 p.

Barnes, H.H., Jr., 1967, Roughness characteristics of natural channels: U.S. Geological Survey Water-Supply Paper 1849,213 p.

Brown, S.A. and Clyde, E.S., 1989, Design of riprap revetment: Federal Highway Administration Hydraulic Engineering Circular No. 11, Publication FHWA-IP-89-016, 156 p.

Froehlich, D.C., 1989, Local scour at bridge abutments in Ports, M.A., ed., Hydraulic Engineering--Proceedings of the 1989 National Conference on Hydraulic Engineering: New York, American Society of Civil Engineers, p. 13-18.

Hayes, D.C.,1993, Site selection and collection of bridge-scour data in Delaware, Maryland, and Virginia: U.S. Geological Survey WaterResources Investigation Report 93-4017, 23 p.

Interagency Advisory Committee on Water Data, 1982, Guidelines for determining flood flow frequency: U.S. Geological Survey, Bulletin 17B of the Hydrology Subcommittee, 190 p.

Johnson, C.G. and Tasker, G.D.,1974, Progress report on flood magnitude and frequency of Vermont streams: U.S. Geological Survey Open-File Report 74-130, 37 p.

Lagasse, P.F., Schall, J.D., Johnson, F., Richardson, E.V., Richardson, J.R., Chang, F., 1991, Stream Stability at Highway Structures: Federal Highway Administration Hydraulic Engineering Circular No. 20, Publication FHWA-IP-90-014, 195 p.

Laursen, E.M., 1960, Scour at bridge crossings: Journal of the Hydraulics Division, American Society of Civil Engineers, v. 86, no. HY2, p. 39-53.

Richardson, E.V. and Davis, S.R., 1995, Evaluating scour at bridges: Federal Highway Administration Hydraulic Engineering Circular No. 18, Publication FHWA-IP-90-017, 204 p.

Richardson, E.V., Harrison, L.J., Richardson, J.R., and Davis, S.R., 1993, Evaluating scour at bridges: Federal Highway Administration Hydraulic Engineering Circular No. 18, Publication FHWA-IP-90-017, 131 p.

Richardson, E.V., Simons, D.B., and Julien, P.Y., 1990, Highways in the river environment: Federal Highway Administration Publication FHWA-HI-90-016.

Ritter, D.F., 1984, Process Geomorphology: W.C. Brown Co., Debuque, Iowa, 603 p.

Shearman, J.O., 1990, User's manual for WSPRO--a computer model for water surface profile computations: Federal Highway Administration Publication FHWA-IP-89-027, 187 p.

Shearman, J.O., Kirby, W.H., Schneider, V.R., and Flippo, H.N., 1986, Bridge waterways analysis model; research report: Federal Highway Administration Publication FHWA-RD-86-108, 112 p.

U.S. Department of Transportation, 1993, Stream stability and scour at highway bridges, Participant Workbook: Federal Highway Administration Publication FHWA HI-91-011.

U.S. Geological Survey, 1966, Randolph, Vermont 7.5 Minute Series quadrangle map: U.S. Geological Survey Topographic Maps, Scale $1: 24,000$. 


\section{APPENDIX A: \\ WSPRO INPUT FILE}




\section{WSPRO INPUT FILE}

*

HP 2 BRIDG

HP 2 RDWAY

HP 1 APPR

HP 2 APPR

*

HP 1 BRIDG

HP 2 BRIDG

HP 2 RDWAY

APPR
U.S. GEOLOGICAL SURVEY WSPRO INPUT FILE brai012.wsP

CREATED ON 27-APR-95 FOR BRIDGE BRAITH00230012 USING FILE brai012.dCa HYDRAULIC ANALYSIS OF BRAI012 OVER AYERS BROOK IN BRAINTREE, VT

$\begin{array}{lllllllllllllllllllll}6 & 29 & 30 & 552 & 553 & 551 & 5 & 16 & 17 & 13 & 3 & * & 15 & 14 & 23 & 21 & 11 & 12 & 4 & 7 & 3\end{array}$

$16702360 \quad 1215$

$0.003 \quad 0.003 \quad 0.003$

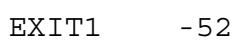

Expansion coefficient increased from default 0.5 to 1.0 between the full valley section and the approach due to approach being much more constricting than the exit section. This will only affect the unconstricted model run and will not change the results of the profile through the bridge.

FULLV $\quad 0 * 1.0 * 0.003$

$0 \quad 999.3 \quad 45$

$0.0,999.46$

$8.2,988.89$

$1.0,990.91$

$1.5,990.19$

$4.0,989.48$

$21.2,990.32$

$12.5,989.11$

$16.3,989.76$

$20.2,989.67$

0.034

$119 * * 17.52 .5$
$22.8,999.12$

$0.0,999.46$

RDWAY $\quad 10 \quad 16 \quad 2$

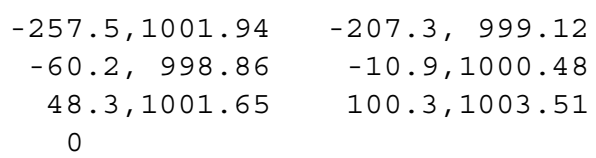

actual approach stationing was 86 feet but bed from bridge to approach was 0 grade so changing SRD to 46. Also changing the graphical estimate of $\mathrm{BP}=65$ to value below for curvilinear flow

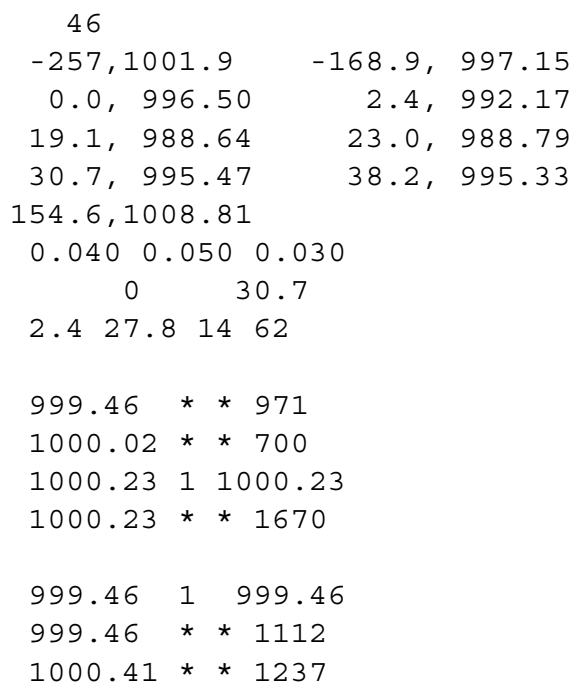




\section{APPENDIX B: \\ WSPRO OUTPUT FILE}




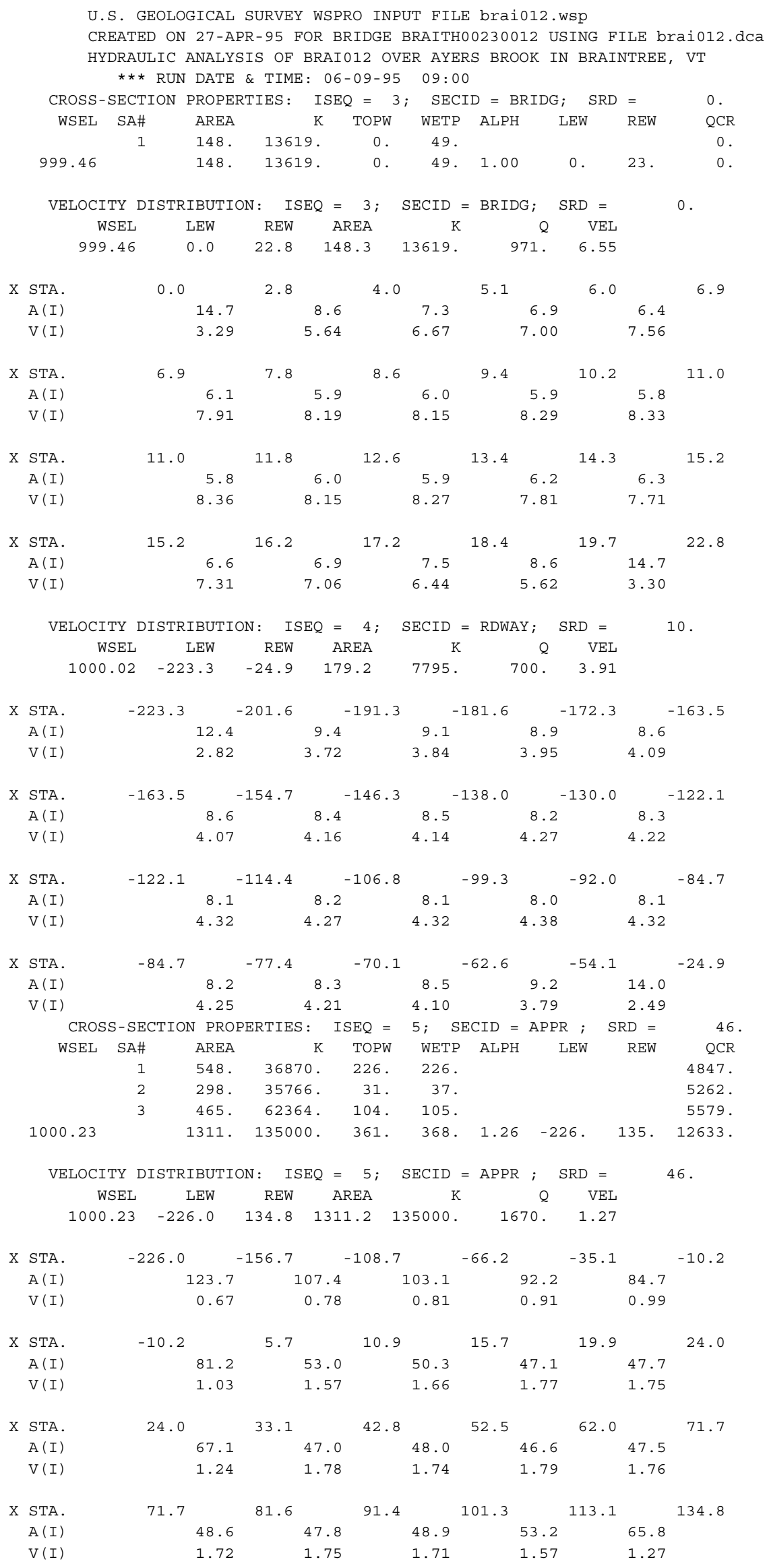


WSPRO OUTPUT FILE (continued)

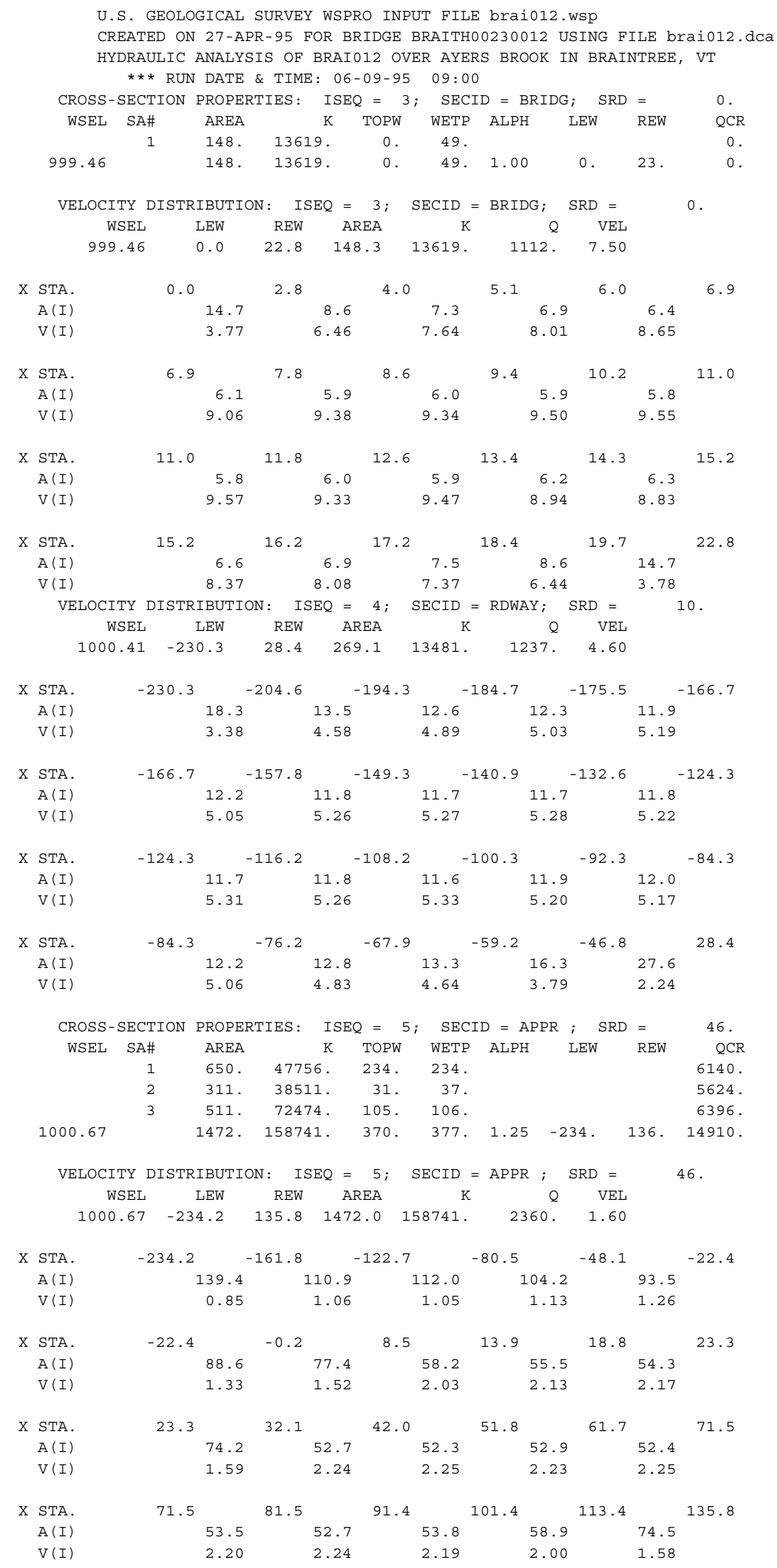


WSPRO OUTPUT FILE (continued)

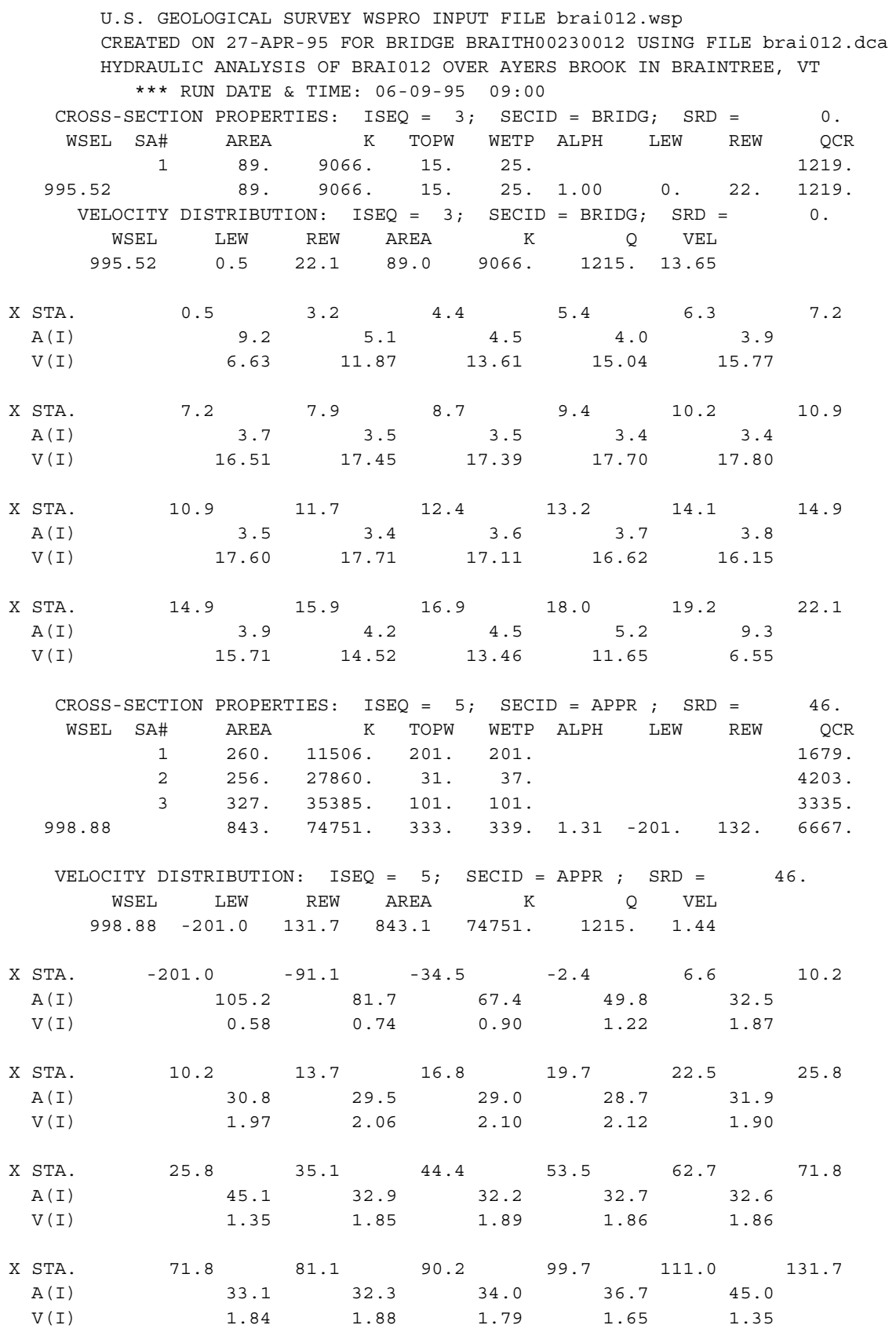


WSPRO OUTPUT FILE (continued)

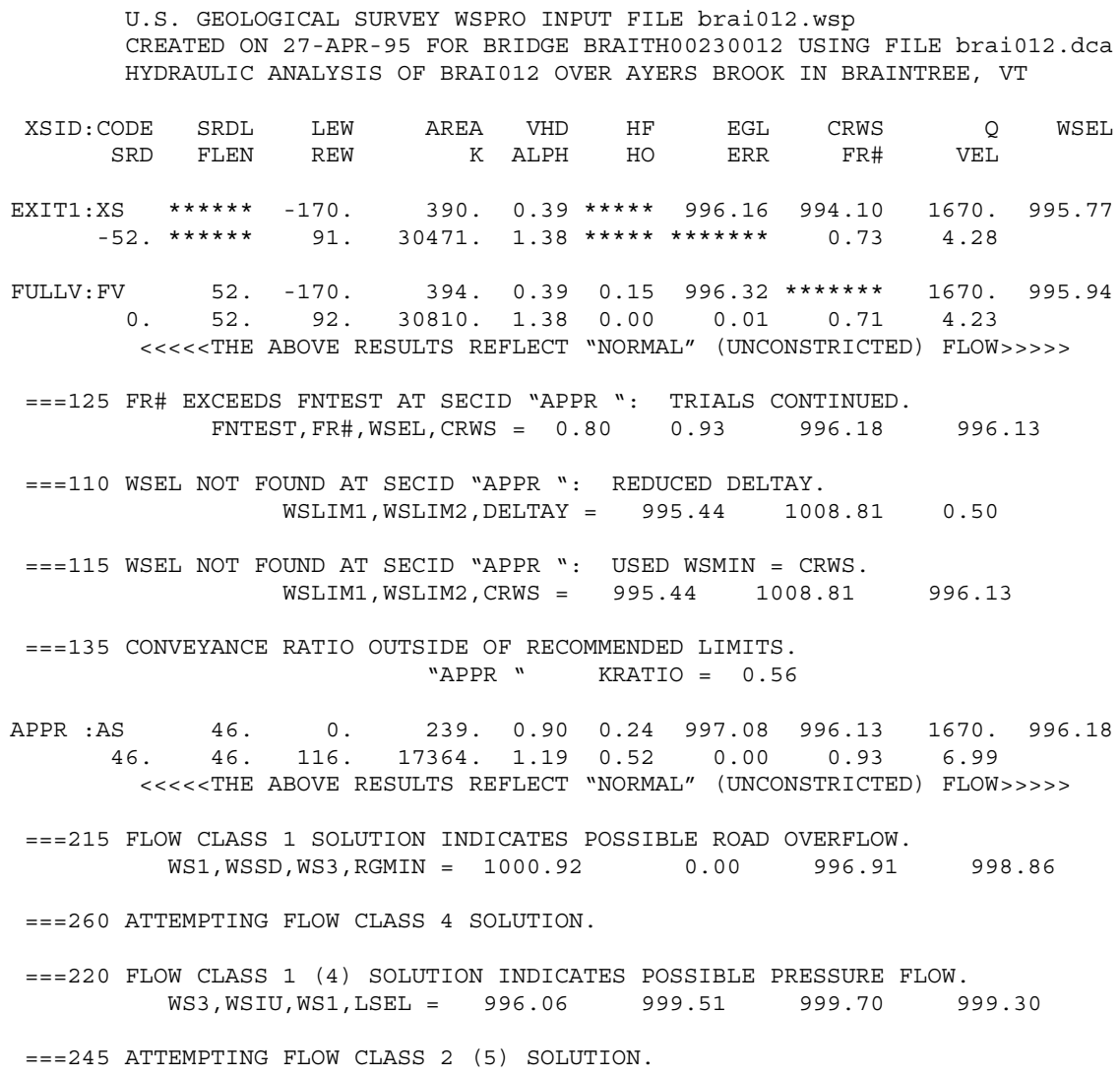


WSPRO OUTPUT FILE (continued)

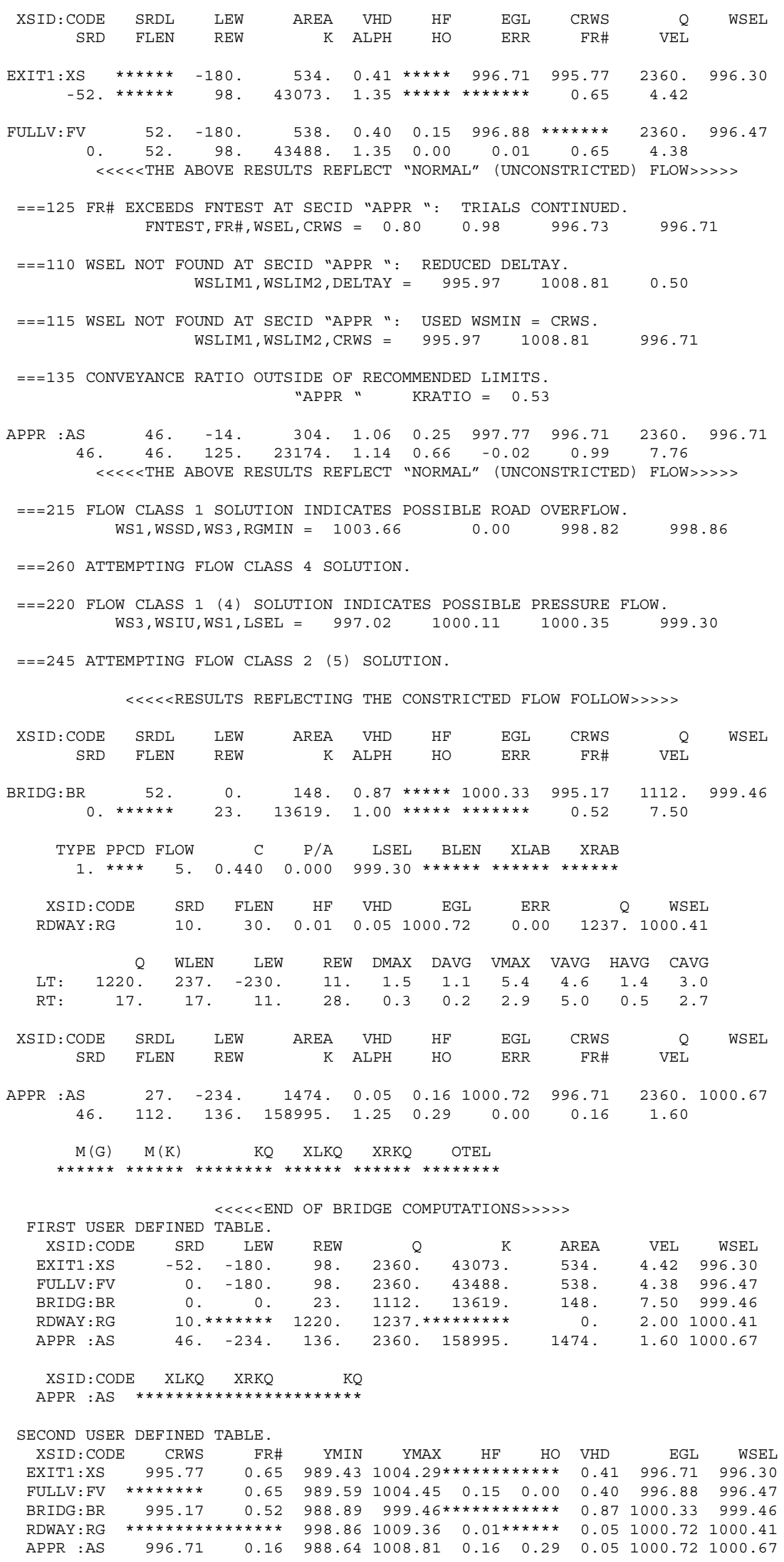


WSPRO OUTPUT FILE (continued)

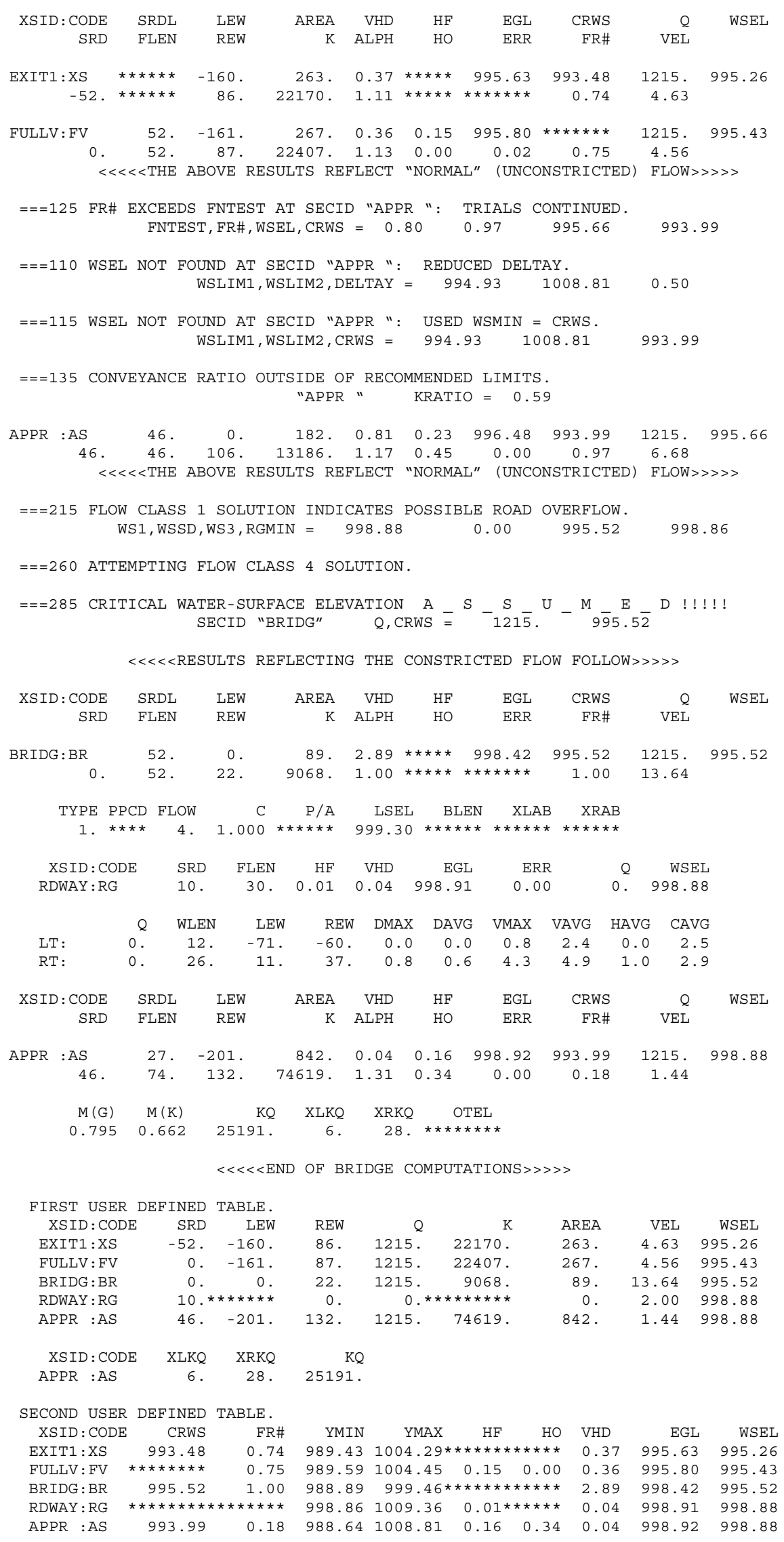




\section{APPENDIX C:}

\section{BED-MATERIAL PARTICAL-SIZE DISTRIBUTION}




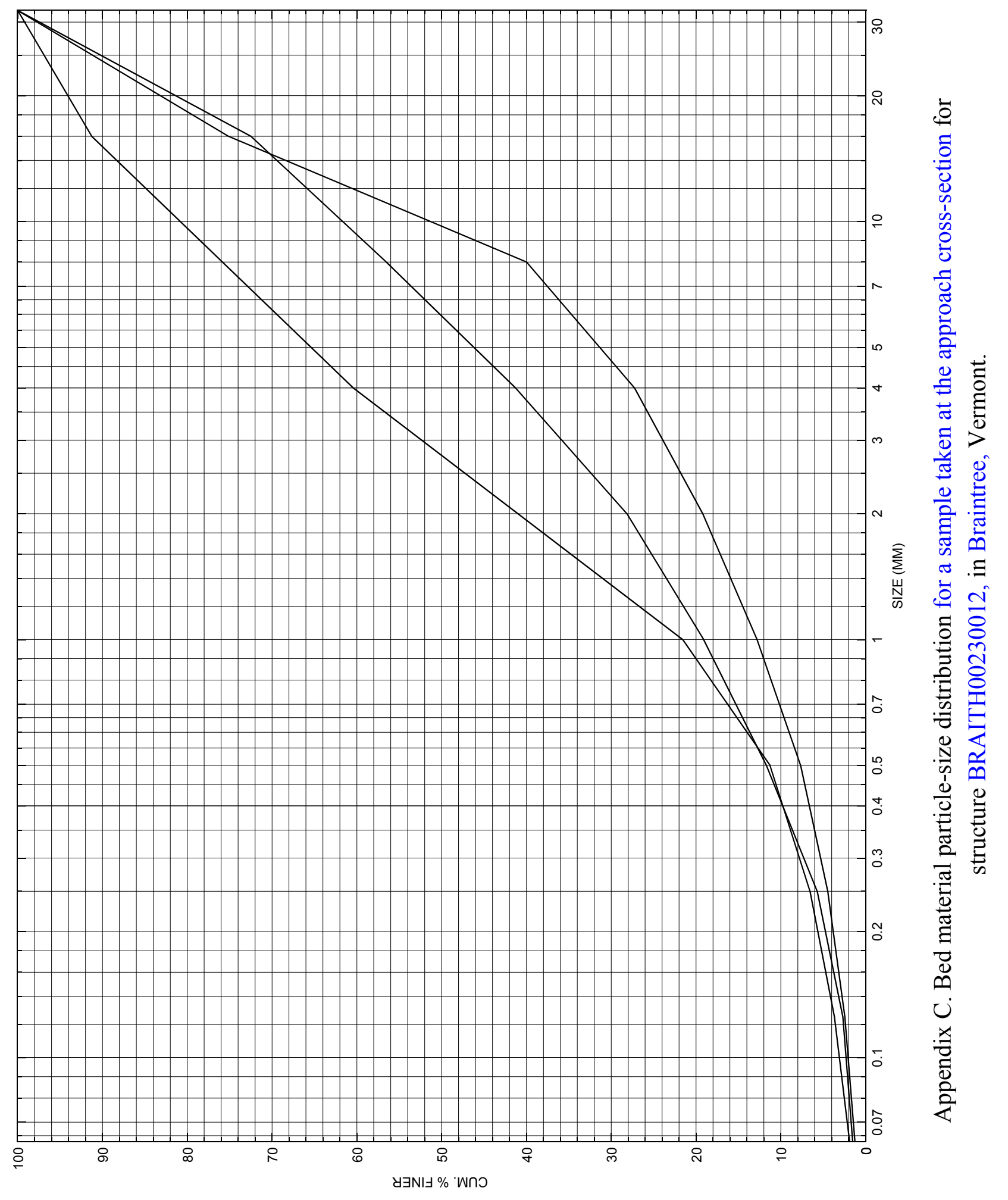




\section{APPENDIX D: \\ HISTORICAL DATA FORM}

